\title{
Learning Mathematical Modeling: How is Junior High School Students' Motivation Through Visual_Formed Problems?
}

\author{
F Arni ${ }^{1}$, Darmawijoyo ${ }^{2, *}$ and Simarmata, R. $\mathrm{H}^{3}$ \\ ${ }^{123}$ Mathematics Education Department, Sriwijaya University, Palembang, South Sumatra, Indonesia
} Email:_darmawijoyo@unsri.ac.id

\begin{abstract}
The purpose of this descriptive research was to see the effects of visual-formed problems on junior high school students' motivation to learn mathematics using a mathematical modeling framework measured using several learning motivation indicators. This research was conducted to 27 students grade VII.2 of SMP Adabiyah Palembang. The questionnaire analysis results showed that the average student learning motivation on mathematics had increased with $51,85 \%$ of students having high learning motivation, $48,15 \%$ of students having medium motivation, and $0 \%$ of students having low motivation.
\end{abstract}

Keywords: Mathematical Modeling, Visual-Formed Problem.

\section{INTRODUCTION}

Motivation is one of the most important things that should be present in students. Student learning motivation is one of the main determinants of student success. Learning motivation can be weakened, so student achievement decreases [1,2]. The importance of learning motivation embedded in students will make it easier for them to digest and understand the materials they are learning in class. It means that this learning motivation can also affect the level of students' success and achievement. Generally, they have different learning motivation to learn. Those who have high learning motivation will also achieve high achievements [2].

Motivation is one of the factors that affect student learning success [3]. Mathematics is usually taught formally and does not use real contexts. As a result, students dislike it. They consider it a difficult, boring, and monotonous subject $[4,5]$ so their motivation to learn mathematics decreases. This will have an effect on the problem solving performance and student achievement [6]. Those who have good motivation and achievement can be characterized by various factors including being able to think rationally, passionate about the learning process, and have good problem solving skills $[7,8]$.
The low student motivation in mathematics can be renewed by applying mathematical modeling learning. Mathematical modeling can help students to excel in mathematics [9]. Some of the reasons why the mathematical modeling is essential in mathematics learning are, namely: (1) to develop and apply students' sensitivity about the benefits of mathematics so as to encourage them to use the mathematical concepts in their daily life; (2) to bring together mathematics and the real world; (3) to facilitate them in the problem solving process; (4) to make it easier for them to see and master the mathematical concepts; (5) to propose or develop positive attitudes towards mathematics $[10,11]$.

Mathematical modeling is a process by which the real-world problems are translated into mathematical language $[12,13]$. By learning to use the mathematical modeling, students are given story question related to their daily life. The difficulty that they often experience in solving the mathematical story question lies in the too convoluted sentences, so they do not understand the meaning of the word and the meaning of the problem $[14,15]$. By reducing and correcting words then adding pictures to the question, it will have an optimal effect on the learning outcomes that they will achieve [16]. In line with that, Mayer and Novak also said that lessons containing words with pictures contributed to more positive learning outcomes than lessons containing only words $[17,18]$. 
There were several previous studies that used visual question representation in their research. Bustang et all conducted research related to the use of visual activities to develop students' understanding of the concept of angles. Subsequently [19], Suryani \& Lestari examined the use of visual media to increase students' motivation and interest in learning mathematics [20]. In addition, Hoongland et all discussed the effects of student performance by changing the contextual mathematical problems from the descriptive questions to the pictorial questions [16]. Hoongland's research also said that there were still few researchers who discussed this problem. In this research, the use of visual questions was inspired by research conducted by Hoongland et all, stating that students preferred the visual questions to the text questions. Visualization was also able to increase students' understanding of the materials they were studying and could help them get meaningful learning using various learning media, including pictures, chart, visualization, diagram, table, etc [6]. This made the researchers interested in using the visualization media to make it easier for students to understand the concepts and information in the questions given. This research was conducted with the aim of knowing the student's motivation to learn mathematics. It used the mathematical modeling as a learning approach and selected linear inequality with one variable as the material.

Based on the description above, the researchers wanted to conduct a research entitled "Motivation to Learn Mathematics in Junior High School Students Using Visual Question-Based Mathematical Modeling Learning on PtLSV Material". Therefore, the problem formulation in this research was: how was the impact of visual problems on motivation to learn mathematics in Junior High School students using mathematical modeling learning on PtLSV material? This research would reveal the effects of visual questions on the motivation to learn mathematics in Junior High School students using the mathematical modeling learning on PtLSV material. Motivation is defined as the students' inner driving force that will make them more active in learning and have a high focus on learning so that they can achieve the desired goals [21,2]. In the learning process, it is necessary to have learning motivation since those who do not have learning motivation will not be able to carry out the learning activities $[22,4]$.

\section{RESEARCH METHOD}

This was descriptive research. Descriptive research is research that describes a phenomenon or event factually and accurately $[23,24]$. This research aimed to describe and determine the effects of visual problems on motivation to learn mathematics in Junior High School students using the learning mathematical modeling on the linear inequality with one variable material. It was conducted at SMP Adabiyah Palembang located on M. Isa Street, Punai II Hallway, South Sumatra, Palembang. The subjects were students grade VII.2 of SMP Adabiyah Palembang in the 2019/2020 school year.

In this research, the data were collected by using questionnaire, interview, and observation techniques. The questionnaire was used to determine the level of student's motivation to learn mathematics individually. On the other hand, the interview was used to see the student motivation after the visual mathematical modeling learning. In contrast, the observation was used as the supporting data to see student behavior during learning.

The research instruments were in the form of a pretest, namely ordinary story question with linear inequality with one variable material, a questionnaire pra-treatment and post-treatment used to see student's motivation to learn mathematics, lesson plan for grade VII on the linear inequality with one variable material so that the learning run systematically and regularly, Student Worksheet (LKPD) with the visual questionbased mathematical modeling problems with linear inequality material, and interview guidelines as a reference to see the students' views and motivation to learn the visual question-based mathematical modeling problems.

The appearance of the visual question used can be seen in the following figure.
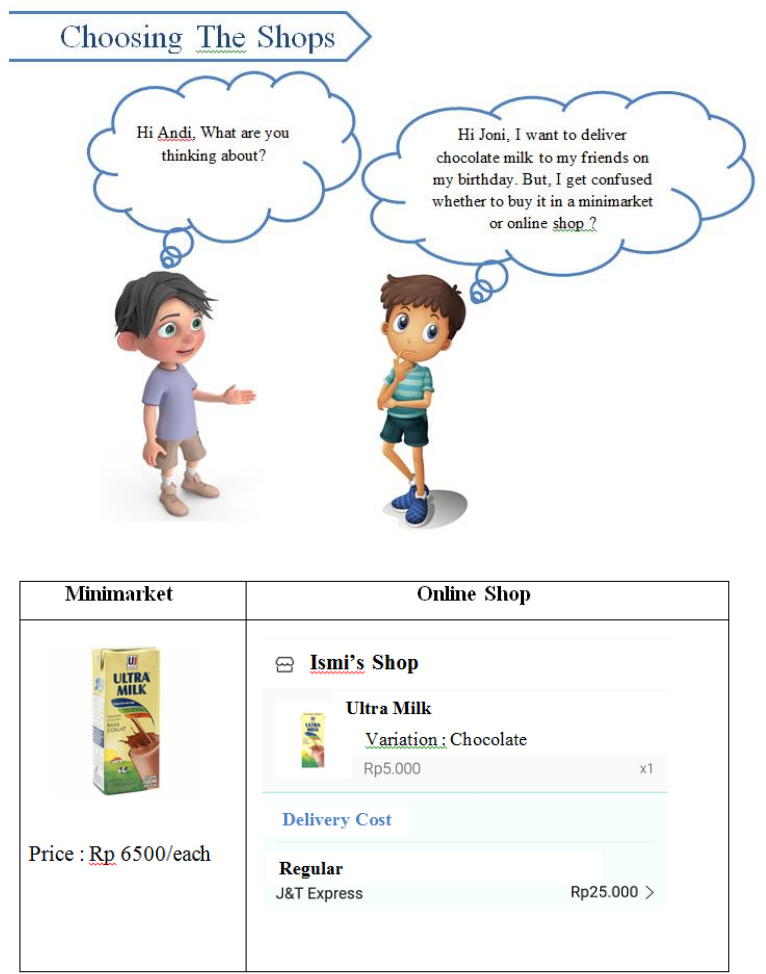

Figure 1 Visual Question 
This research was conducted for 2 days. On the first day, a pre-test was carried out to test students' initial knowledge of the material to be discussed. Then, the results were used to divide them into several groups. A pre-treatment questionnaire was also given to determine their motivation to learn mathematics. On the second day, the mathematical modeling approach was introduced. Each group worked on Student Worksheet (LKPD), then they filled out a post-treatment questionnaire to see their motivation to learn mathematics in the mathematical modeling approach learning. After that, interview was conducted with the research subjects (3 students who had excellent, good and adequate learning motivation were chosen).

Learning motivation in this research could be measured by ARCS aspects; Attention, Relevance, Satisfaction, Confidence) with several indicators that have been developed [25,26]. The grouping of the motivation scores into high, medium, and low categories was by adding up the scores of each question in the questionnaire based on the following conditions:

Table 1. Category of student learning motivation

\begin{tabular}{cc}
\hline Value Interval & Category \\
\hline$M \geq M i+S D i$ & High \\
$\overline{M i}-S D i \leq M<\overline{M i}+S D i$ & Medium \\
$M<M i-S D i$ & Low \\
\hline
\end{tabular}

Description:

$$
\begin{aligned}
M & =\text { motivation score } \\
M i & =\text { mean ideal } \\
& =\frac{1}{2}(\text { max score }+ \text { min score }) \\
S D i & =\text { ideal standard deviation } \\
& =\frac{1}{6}(\text { max score }- \text { min score })
\end{aligned}
$$

The questionnaire data were scored based on the Likert scale which had five answer categories, namely Strongly Agree / Always (SA), Agree / Often (A0, Doubt / Sometimes (D), Disagree / Rarely (DA), and Strongly Disagree / Never (SDA). If the statement given was a positive statement, then the scores given were SA with 5 , A with 4, D with 3 , DA with 2 and SDA with 1 . As for the negative statement, the scores given were SA with 1 , A with 2 , D with 3 , DA with 4 and SDA with 5.

\section{FINDINGS AND DISCUSSION}

\subsection{Findings}

In this research, the student's motivation to learn mathematics was measured by questionnaire pratreatment and post-treatment, interview and supported by observational data. Based on the questionnaire results, from 27 students who filled out the questionnaire, only 7 students who had high learning motivation. It can be seen in table 2 below.

Table 2 Recapitulation of pre-treatment of students' motivation to learn mathematics

\begin{tabular}{cccc}
\hline Score Range & $\begin{array}{c}\text { Freque } \\
\text { ncy }\end{array}$ & $\begin{array}{c}\text { Percenta } \\
\text { ge }\end{array}$ & Category \\
\hline$M \geq 36,66$ & 6 & $22,22 \%$ & High \\
$23,34 \leq M<36,66$ & 16 & $59,26 \%$ & Medium \\
$M<23,34$ & 5 & $18,52 \%$ & Low \\
\hline
\end{tabular}

The table 2 shows that there were 6 students with high learning motivation $(22,22 \%), 16$ students with medium learning motivation $(59,26 \%)$, and 5 students with low motivation $(18,52 \%)$. Based on these data, it can be concluded that the student learning motivation after doing the pre-test was in the medium category. Those who had high learning motivation were still relatively few since most students found mathematics difficult to understand. In line with that, in Sabrina's et all research, the low motivation to learn mathematics in classroom was due to the lack of learning media used by the teacher. As a result, learning mathematics in the classroom became boring and monotonous since they ended up being passive and only listened to the teacher's explanation.

Based on the post-treatment questionnaire results, there were 27 students who filled out the questionnaire. Moreover, there was a significant increase in the student learning motivation category after learning with the mathematical modeling. The questionnaire results can be seen in table 3 below.

Table 3. Recapitulation of post-treatment of students' motivation to learn mathematics

\begin{tabular}{cccc}
\hline Score Range & $\begin{array}{c}\text { Freque } \\
\text { ncy }\end{array}$ & $\begin{array}{c}\text { Percent } \\
\text { age }\end{array}$ & $\begin{array}{c}\text { Catego } \\
\text { ry }\end{array}$ \\
\hline $\boldsymbol{M} \geq \mathbf{3 6 , 6 6}$ & 14 & $51,85 \%$ & High \\
$\mathbf{2 3}, \mathbf{3 4} \leq \boldsymbol{M}<\mathbf{3 6 , 6 6}$ & 13 & $48,15 \%$ & Medium \\
$\boldsymbol{M}<\mathbf{2 3}, \mathbf{3 4}$ & 0 & $0 \%$ & Low \\
\hline
\end{tabular}


The table 3 shows that there were 14 students with high learning motivation (51.85\%), 13 students $(48.15 \%)$ with moderate learning motivation, and no students with low motivation. Based on these data, it can be concluded that the student learning motivation after learning with visual- question-based mathematical modeling was in the high category. The results revealed that they had quite good mobility when participating in the visual- question-based mathematical modeling learning in the classroom, so their learning motivation increased. The power of student movement could also be seen from their attitudes and behavior when learning took place.

Based on the observation data during the learning, it appears that students had good attention when the learning process was carried out. Most of them really paid attention to the explanation from the teacher. They also had the willingness to find and look for visible information when they tried to work on Student Worksheet (LKPD) given by the teacher. They were also able to link the learning being taught with their daily life, seen when they answered the questions asked by the teacher at the beginning of the lesson, namely questions about shopping at supermarkets and online shopping. This fulfilled the second indicator, namely relevance. In the confidence indicator, during the learning, it is seen when the teacher asked who wanted to mention one of the answers to the questions from Student Worksheet (LKPD) and several students raised their hands to answer the questions. This showed a sense of self-confidence in them. In the implementation video, it can also be seen that they could complete the assignment even though some of them had difficulties and asked a lot of questions in doing it. The last indicator was satisfaction. It concerned their activeness in learning that took place. In the video, it can be seen that some students often asked questions and dared to convey/present the results of their group work in front of the class.

In this research, the student learning motivation was also measured by the interview method. The interview was analyzed using the learning motivation indicators. The indicators used in the interview guidelines are:

- The presence of enthusiasm and motivation in learning

- The presence of interesting activities in learning

- $\quad$ The presence of seriousness in learning

- The presence of confidence in their own skills

The following are the excerpts of interviews that the researchers had conducted with the research subjects (SP1, SP2 and SP3).

- Regarding the presence of enthusiasm and motivation in learning
$\mathrm{P} \quad$ : "Should we discuss the question that I give more frequently in the class?"

$$
\text { SP1 : "Yes." }
$$

P : "Why?"

SP1 : "Because it is like a problem in our daily life."

Based on SP1's answer, SP1 agreed if the mathematical modeling questions were to be discussed more frequently in the class. It showed the presence of learning motivation in the students. SP1 said that the reason was because the question was a problem in the daily life. According to Cheng's statement, mathematical modeling is a process of understanding, simplifying and solving problems in real life [29].

P : : Okay, should we discuss the question that I give more frequently in the class?"

$$
\text { SP2 : "Yes." }
$$

Based on the interview results, SP2 agreed if the mathematical modeling questions were to be discussed more frequently in the class.

P : :Okay, should we discuss the question that I give more frequently in the class?"

SP3 : "Yes, your question was stickier to my brain."

SP3 agreed if the question given by the researchers were to be discussed more frequently in the class since it made it easier for SP3 to remember and understand the lessons.

- Regarding the presence of interesting activities in learning

$\mathrm{P} \quad$ : "Do you prefer learning using the visual question such as posters that I use compared to the ordinary story question?

SP1 : "I prefer the visual one."

P : "Why?"

SP1 : "More exciting, more passionate."

It seems that SP1 preferred the visual question to the ordinary story question. It showed that the former were more interesting than the latter. This was consistent with the statement that using visualization to make students competent about a topic was very significant in bringing their interest to the lesson [6].

P : "Do you prefer learning using the visual question such as posters that I use compared to the ordinary story question?"

SP2 : "I prefer the visual question since it could be more innovative and the pictures could be more inspiring. More exciting." 
According to SP2, the visual question could innovate learning, provide inspiration, and make it more enthusiastic. This was consistent with the statement that using visualization to make students competent about a topic was very significant in bringing their interest to the lesson [6]. It showed SP2's interest in learning with the visual question.

P : "Do you prefer learning using the visual question such as posters that I use compared to the ordinary story question?"

SP3 : "Yes, more interesting."

It seems that SP3 preferred the visual question because it was more interesting than the ordinary story question.

- $\quad$ Regarding the presence of seriousness in learning

$\mathrm{P} \quad$ : "Are you more serious about doing the question discussed with me than the mathematical questions in your textbook?"

SP1 : "It is more serious when discussed with you since if for example in the textbook, if for example it was wrong, there was no one... what's that, if for example there was something wrong, it do not inform me right away, so it is not suitable, so why the answer is this, it is wrong right at the beginning, if it is discussed with you it is not wrong at the beginning."

From the answer, it can be seen that SP1 was more serious about working on the modeling question discussed with the researchers since the researchers directed the students to double-check their answers to each question. Accordingly, there were no mistakes in the final result. This corresponded to the mathematical modeling process, namely iterate which meant repeating the process (rechecking)

$\mathrm{P} \quad$ : “Okay. Are you more serious about doing the question discussed with me than the mathematical questions in your textbook?'

SP2 : "We have to be serious if we study because if we are not serious nothing will get into our brain."

$\mathrm{P} \quad$ : "But which one is more serious?"

SP2 : "Ehm.. more serious with you since if it is in the books, I can study it again."

Based on this interview, it appears that SP2 was more serious in working on the visual question given by the researchers since the questions in the book could be studied again later.

P : "Okay. Are you more serious about doing the question discussed with me than the mathematical questions in your textbook?"

SP3 : "Yes."
P : :Why?"

SP3 : "More exciting."

It can be seen that SP3 was more serious in working on the question given by the researchers since the learning was more exciting.

- Regarding the presence confidence in their own skills

P : "Are you sure that by doing the question that I give, you can do the ordinary mathematical questions?"

SP1 : "Yes, because... the question that you give is the basic concept, so for other questions, if God wills, I can do it."

It appears that SP1 was sure that by working on the question the researchers gave (the mathematical modeling question), SP1 could work on the ordinary mathematical questions because the question the researchers gave was basic concept, so SP1 was sure that SP1 could work on other questions.

$\mathrm{P} \quad$ : "Are you sure that by doing the question that I give, you can do the ordinary mathematical questions?"

SP2 : "Yes, since your question does not only need formula, but we can think about it. You also teach with thinking, .. it does not have to be related to formula."

SP2 argued that the question the researchers gave did not need formula, but SP2 could think about it. The researchers understood the meaning of SP2's statement, namely that SP2 could do mathematics without formulas, but based on thinking.

$\mathrm{P} \quad$ : "Are you sure that by doing the question that I give, you can do the ordinary mathematical questions?"

SP3 : "Yes, more stickier in my brain."

It meant that the learning done by the researchers made it easier for SP3 to remember the learning.

In the interview transcript, it can be seen that in answering the question given by the researchers, the answers of SP1, SP2 and SP3 had met the four learning motivation indicators, namely the presence of enthusiasm and motivation in learning; interesting activities in learning, seriousness in learning, and confidence in their own skills.

\subsection{Discussions}

This research aimed to determine the role or effect of visual question-based mathematical modeling learning on the learning motivation students grade VII.2 of SMP Adabiyah Palembang on the linear inequality 
with one variable material shown through the questionnaire data, interview results, and observation videos. After participating in learning with the visual question-based mathematical modeling, it appears that none of them had low learning motivation and the dominant students had high learning motivation, namely by $51.85 \%$. The student learning motivation is generally affected by several factors, namely factors originating from the teacher and students [27]. One of the factor coming from students is the learning environment. As the learning process progresses, an active learning environment can motivate students to study harder and more active [28]. By comparison, the factors affecting the student learning motivation are the interaction between students and teachers and the selection of learning models to be used [25]. Hence, the role of the teacher is very crucial in choosing the learning models and learning media to increase the students' enthusiasm for learning and make learning more meaningful.

By using the mathematical modeling, it could make learning more meaningful and help students succeed in mathematics lessons [9]. The visual Student Worksheet (LKPD) used in this research used the context of choosing a store, namely a minimarket or online store. The selection of context was inspired by the research conducted by Hoongland et all stating that the students preferred the visual questions than the text questions [16]. Visualization was also able to increase the students' understanding of the material being studied [6]. Based on the results of interviews conducted with 3 students, they found learning with the mathematical modeling interesting and exciting. From the interview results, the researchers concluded that the three students met the learning motivation indicators due to the occurrence of each indicator in each student's answer.

During the learning, it is seen that the students had good attention when the learning process was carried out. They also had the willingness to find and look for visible information when they tried to work on Student Worksheet (LKPD) given by the teacher and some of them appear to be active when the learning took place.

\section{CONCLUSIONS}

Based on the discussion above, it can be concluded as follows the visual question had the potential to improve the quality of learning outcomes since the student learning motivation increased. Secondly, the visual question was in line with van de Halle's theory, namely that it could be a starting point for understanding the real problems. Thirdly, the visual questions would make it easier for the students to learn problem solving since it was easier to identify the problems.

\section{REFERENCES}

[1] M. Dimyati, Belajar dan Pembelajaran, Jakarta: PT Rajagrafindo Persada, 2006.

[2] G. Hamdu , Agustina L, "Pengaruh Motivasi Belajar Siswa Terhadap Prestasi Belajar IPA di Sekolah Dasar," Jurnal Penelitian Pendidikan, pp. 90-96, 2011.

[3] M. Najichun , W. Winarso, "Hubungan Persepsi Siswa Tentang Guru Matematika dengan Hasil Belajar Matematika Siswa," IAIN Syekh Nurjati, Cirebon, 2017.

[4] R. Retnasari , J. Maulana, "Pengaruh Pendekatan Kontekstual terhadap kemampuan Koneksi matematis dan motivasi belajar siswa sekolah dasar kelas iv pada materi bilangan bulat," Jurnal Pena Ilmian, pp. Vol, 1, 2016.

[5] R. Sabrina, F. Fauzi, M.Y.M. Yasmin, "FaktorFaktor Penyebab Rendahnya Motivasi Belajar Siswa dalam Proses Pembelajaran Matematika di Kelas V Sd Negeri Garot Geuceu Aceh Besar," Jurnal Ilmiah Mahasiswa Pendidikan Guru Sekolah Dasar, p. 2, 2017.

[6] A. Özkan, E.E. Arikan, E.M. Özkan, "A Study on the Visualization Skills of 6th Grade Students," Universal Journal of Educational Research, pp. 354-359., 2018.

[7] L. Sahidin, D. Jamil, "Pengaruh motivasi berprestasi dan persepsi siswa tentang cara guru mengajar terhadap hasil belajar matematika. Jurnal Pendidikan Matematika," pp. 211-222, 2013.

[8] A. Kiswoyowati, "Pengaruh motivasi belajar dan kegiatan belajar siswa terhadap kecakapan hidup siswa. Portal Jurnal Universitas Pendidikan Indonesia," pp. 12-16, 2011.

[9] A. Arseven, "Mathematical Modelling Approach in Mathematics Education," Universal Journal of Educational Research, pp. 973-980, 2015. M. K, "Cllasification Scheme fer Modelling Tasks," J Math Didakt, pp. 285-311, 2010.

[10] K. Maab, "Cllasification Scheme fer Modelling Tasks," J Math Didakt, pp. 285-311, 2010.

[11] H. Pratikno, "Analisis Kompetensi Pemodelan Matematika Siswa SMP pada Kategori Kemampuan Matematika Berbeda," ProsidingPm15. Universitas Muhammadiyah Surakarta, 
Jawa Tengah, 2019.

[12] K. C. Ang, "Teaching Mathematical Modelling in Singapore Schools," The Mathematics Educator, pp. 63-75, 2001.

[13] D. Suryanto, H. Hapizah, "Kemempuan Pemodelan Matematika Siswa Dengan Pendekatan Model Eliciting Activities (Meas) Pada Materi Pola Bilangan," Doctoral dissertation, Sriwijaya University, 2019.

[14] N. Farida, "Analisis kesalahan siswa SMP kelas VIII dalam menyelesaikan masalah soal cerita matematika," AKSIOMA: Jurnal Program Studi Pendidikan Matematika, 2015.

[15] U. Khasanah, Sutama, "Kesulitan Menyelesaikan Soal Cerita Matematika Pada Siswa SMP," Universitas Muhammadiyah Surakarta, Jawa Tengah, 2015.

[16] K. Hoogland, B.Pepin, J. De Koning, A. Bakker, K. Gravemeijer, "a Word Problems Versus ImageRich Problems: an Analysis of Effect of Task Characteristics on Students' Performance on Contextual Mathematics Problems," Research in Mathematics Education, pp. 37-52, 2018.

[17] R. E. Mayer "Incorporating motivation into multimedia learning," Learning and Instruction, pp. 171-173, 2014.

[18] E. Novak, "Toward a mathematical model of motivation, volition, and performance," Computers \& Education, pp. 73-80, 2014.

[19] B. Bustang, et all, "Developing a Local Instruction Theory for Learning the Concept of Angle through Visual Field Activities and Spatial Representations," International Education Studies, pp. 58-70, 2013.

[20] D. R. Suryani, N. Lestari, "Penggunaan variasi media pembelajaran untuk meningkatkan motivasi dan minat belajar matematika siswa kelas XI ips 3 SMA Negeri 2 Merauke," Musamus Journal of Mathematics Education, pp. 74-79, 2019.

[21] K. T. Aritonang, "Minat dan motivasi dalam meningkatkan hasil belajar siswa," Jurnal pendidikan penabur, pp. 11-21, 2008.

[22] S. B. Djamarah, "Psikologi belajar.," 2011.

[23] N. Dantes, "Metode Penelitian," ANDI,
Yogyakarta, 2012.

[24] D. Masyitoh, "Analisis Kemampuan Mengkonstruksi Model Matematika dengan Pendekatan Model Eliciting Activities (MEAs) di SMA N 10 Palembang," 2018.

[25] N. Sari, W. Sunamo, S. Sarwanto, "Analisis Motivasi Belajar Siswa dalam Pembelajaran Fisika Sekolah Menengah Atas," Jurnal Pendidikan dan Kebudayaan, 2018.

[26] J. M. Keller, "Development and use of the ARCS model of instructional design," Journal of instructional development, 1987.

[27] Hynd, H. Jodi, N. Sherrie, "Learning complex scientific information: Motivation theory and its relation to student perceptions," Reading \& Writing Quarterly, pp. 23-57, 2000.

[28] C. A. T. Cicuto, "Implementing an active learning environment to influence students' motivation in biochemistry," Journal of Chemical Education, pp. 1020-1026, 2016.

[29] K. C. Ang, "Mathematical modeling and real life problem solving. In B.Kaur B $\mathrm{H}$, Yeap \& $\mathrm{M}$, Kapur. (Eds) Mathematical Problem Solving," Association of Mathematics Educators Yearbook, p. 159-182, 2009. 